\title{
Performance Analysis of an Energy System in the Tropical Rainforest: A Thermo-Economic Approach
}

\author{
Barinyima Nkoi' ${ }^{1}$, Kenneth Israel ${ }^{1}$, Sidum Adumene ${ }^{2}$ \\ ${ }^{1}$ Department of Mechanical Engineering, Rivers State University, Port Harcourt, Nigeria \\ ${ }^{2}$ Department of Marine Engineering, Rivers State University, Port Harcourt, Nigeria \\ Email:nkoi.barinyima@ust.edu.ng,kentgalaxy@yahoo.com,sidum.adumene@ust.edu.ng
}

How to cite this paper: Nkoi, B., Israel, K. and Adumene, S. (2018) Performance Analysis of an Energy System in the Tropical Rainforest: A Thermo-Economic Approach. Journal of Power and Energy Engineering, 6, 8-20.

https://doi.org/10.4236/jpee.2018.61002

Received: October 31, 2017

Accepted: January 14, 2018

Published: January 17, 2018

Copyright $\odot 2018$ by authors and Scientific Research Publishing Inc. This work is licensed under the Creative Commons Attribution International License (CC BY 4.0).

http://creativecommons.org/licenses/by/4.0/

(c) (i) Open Access

\begin{abstract}
This paper presents the thermos-economic evaluation of a simple gas turbine (SGT) within the Niger Delta, Nigeria. Steady-state monitoring and direct collection of data from the $25 \mathrm{MW}$ plant were performed including logged data for a 12 months period. MATLAB software was used to model the various thermodynamic performance equations of the plants while net present value (NPV), internal rate of return (IRR), and Payback period (PBP) were used to model the economic concept of the plant performance. The thermodynamic analysis shows that for every $1^{\circ} \mathrm{C}$ rise in the ambient temperature, the percentage power drop increases by $2.07 \%$, thermal efficiency drops by $0.66 \%$, and the specific fuel consumption increases by $0.93 \%$. For every $1 \%$ drop in the power output, the percentage thermal efficiency drops by $0.79 \%$ for the given consideration. The economic analysis based on the performance reveals that the power shortages represent about $47.9 \%$ of the net power generated and the revenue worth of $\$ 4198741.60$ is lost due to the inability of the plant to perform at its design point. The NPV value of $\$ 6434899.97$ shows that the plant investment is viable for the period of twenty years of operation and the IRR on investment is determined to be $12.40 \%$ by a numerical approximation for the period, with a PBP of 8.5 years. This provides technical and economic details to plant operators and energy systems investors for decision making.
\end{abstract}

\section{Keywords}

Gas Turbine, Power Output, Overall Efficiency, Net Present Value, Internal Rate of Return, Payback Period

\section{Introduction}

Energy system performance is critical to any growing economy that is poised for 
growth and sustainability. Researchers have investigated several power plants within the tropical zone, and ways of optimizing their performance have been suggested. Although one way we can achieve energy efficiency is by systematically and effectively minimizing losses in our current energy systems. In addition the establishment of a performance rating philosophy of such systems and their evaluation in terms of technical performance parameters, their cost elements and implications to the environment are pertinent. Our industries today make use of coal, steam electrical energy, furnace, oils, diesel, chemicals, lubricating oil, etc. Although, because of their contribution to global warming, renewable energy development has been in an increasing measure in recent times. Raw materials like steel, copper, aluminum etc. are processed by energy-intensive processes. Even transportation by road, rail, ocean, and air requires high energy input [1]. Without an adequate supply of energy, the stability of the economic order, as well as the political structure of a society is in jeopardy [2]. Hence, energy both its production and its use in an environmentally safe manner is a platform for broader economic growth and improves the quality of life of people around the world [1].

The only form of energy which is easy to produce, transport, use and control is electrical energy. So, it is mostly the terminal form of energy for transmission and distribution [3]. The economic development and living standard of any society are a function of the availability and accessibility of electrical power to do her biding. Although most of the world have had chances to benefit from the merits brought by having access to electrical power, people in developing countries have not been as fortunate. In these countries, providing electricity will increase life expectancy and productivity, and will help in erasing illiteracy [4]. Therefore, the acknowledgment of the importance of increasing access to commercial electricity is fundamental to the future and sustainable development of any society.

The turbine is the most satisfactory power developing unit among various means of producing mechanical power due to its exceptional reliability [5]. Generally, turbines are any kind of spinning that uses the action of a fluid to produce work [6]. They are prime-movers used for driving rotating equipment like pumps, compressors etc., or for generating the electricity required for process industries or a community. The idea of using the axial flow compressors, combustion chamber and turbine was conceived as early as in 1872 [5]. The gas turbine plant can be either open cycle or closed cycle. The major difference between the closed cycle and open cycle is that the working fluid (product of combustion) is continuously circulated in the closed cycle as the fluid coming out from the turbine is cooled to its original temperature in a cooler using an external cooling source before passing into the compressor whereas, in the open cycle, the working fluid is continuously replaced as they are exhausted into the atmosphere [5].

The open cycle gas turbines can be started and stopped so easily compared 
with other power plants and therefore, are used for peak load power and tertiary reserve, and operate for a limited number of hours per year, typically 2000 and 5000 hours. The gas turbines used for electric power generation can produce electric power from the range of 20 to $250 \mathrm{MW}$ with efficiencies of about $40 \%$ [7]. These gas turbines typically have a single-shaft configuration, operate on Brayton cycle [8] and consist of a compressor, a combustion chamber, and a turbine. Air is drawn from the atmosphere and is compressed to a high pressure in the compressor. The high-pressure air enters the combustion chamber where fuel is sprayed (added) to the compressed air and ignited to increase the fuel-air mixture (gas) temperature at constant pressure.

However, gas turbines that operate in simple cycles have low efficiencies because the emission from the turbine exhaust comprises of hot gases and this energy is lost to the atmosphere. In order to better the performance and reduce atmospheric emissions advanced cycles that utilize the energy in the hot emitted gases in a combined cycle to generate more power are being proposed, designed and studied. Efficiencies of about 50\% - 60\% have been reported [9]. Although, as part of performance audit, Adumene [10] presented an exergy-based analysis of an offshore gas plant. The result of his analysis revealed that there is a drop in both the thermal efficiency and exergy efficiency by $0.17 \%$ and $0.25 \%$ respectively, for every $1 \%$ drop in the operational load. The application of the first and second law of thermodynamics provides a holistic result for the plant performance prediction.

Eti et al. [11] made suggestions following series of investigations to improve the performance of the Afam $\mathrm{V}$ power plant by improving the Reliability and Productivity of the plant, and Thamir et al. [12] developed design methodology for a parametric study to improve gas turbine performance. Increase in thermal efficiency depends on certain factors including changes in some engine cycle parameters, such as overall pressure ratio (OPR), and exhaust temperature of the turbine [13]. Nkoi et al. [14], analysis three plant configuration, such as simple gas turbine (SGT), intercooled/recuperated (ICR) engine and recuperated engine $(\mathrm{RC})$ and it was observed that some modified gas turbine cycle configurations incorporating unconventional components such as engine cycle with low-pressure compressor (LPC) zero-staged, recuperated engine cycle, and intercooled/recuperated (ICR) engine cycle exhibited better performances in terms of thermal efficiency and specific fuel consumption than the traditional SGT.

Espanani et al. [15] noted that gas turbines are machines that work directly with ambient air, thus, anything that causes a change in the inlet air condition has an effect on turbine efficiency. Hence, relative humidity, mean sea level and environmental temperature have an effect on gas turbine efficiency. It was observed that fogging and evaporative method is most effective methods of efficiency improvement in Khoramshahr power plant. In Adumene et al. [16] research, it was revealed that decreasing the ambient temperature of the gas turbine plant within the tropical zone by $41.9 \%$ improved the plant performance by about $0.78 \%$. 
Wang and Chiou [17] in their study concluded that implementing both steam injection gas turbine and inlet air cooling features cause more than a $70 \%$ boost in power and $20.4 \%$ improvement in heat rate. Bouam et al. [18] studied combustion chamber steam injecting for gas turbine performance improvement during high ambient temperature operation. Also performed by Harlock et al. [19] was the effect of exergy analysis on the gas turbine inlet temperature, and steam injection level in the gas turbine, and Srinivas et al. [20] concluded that steam injector decreases combustion chamber and gas re-heater energetic loss from $38.5 \%$ to $37.4 \%$ compared to the case without steam injection in combustion chamber. Wadhah [21] introduced an intercooler into the plant analysis and the result shows that the implementation of intercooling increases the power plant thermal efficiency of the case study gas turbine power plant when compared to the non-intercooled gas turbine plant configurations. The above is some of the various methodologies for gas turbine performance improvement, including gas turbine combined cycle. This work seeks to carry out an economic evaluation of the plant performance for its life cycle and predict the possible breaks even point for plant investors and energy mangers.

\section{Materials and Methods}

The following research methodology was adopted:

1) Data were collected from the Trans-Amadi gas plant (a single-shaft gas turbine) through the human machine interface and logbooks for 12 months.

2) Assessment of the plant operating condition was carried out.

3) MATLAB software code was developed to model the various equations employed for the analysis.

4) An economic model with the Net present value as the objective function was developed to predict the economic viability of the plant and to assess the rate of return on the investment.

\section{Analytical Model for Plant Performance Evaluation}

\section{Trans-Amadi Gas Turbine Power Plant Operating Data}

The operating conditions and data of the simple gas turbine, the Trans-Amadi gas turbine power plant is shown in Figure 1. The operating exit temperature of the compressor as shown in Figure 1 is $367^{\circ} \mathrm{C}$ and that of the turbine exit temperature is $487^{\circ} \mathrm{C}$. This illustrate the prevailing conditions where the plant operates, as well as the indication of some limiting factors against which the plant could not delivered at design capacity.

Applying steady flow energy equation and using the notations on the T-S diagram of Figure 1 gives

$$
\begin{gathered}
\text { Heat Supplied, } \dot{Q}_{1}=\dot{m} c_{p}\left(T_{3}-T_{2}\right) \\
\text { Heat Rejected, } \dot{Q}_{2}=\dot{m} c_{p}\left(T_{4}-T_{1}\right) \\
\text { Compressor work rate, } \dot{W}_{c}=\dot{m} c_{p}\left(T_{2}-T_{1}\right)
\end{gathered}
$$




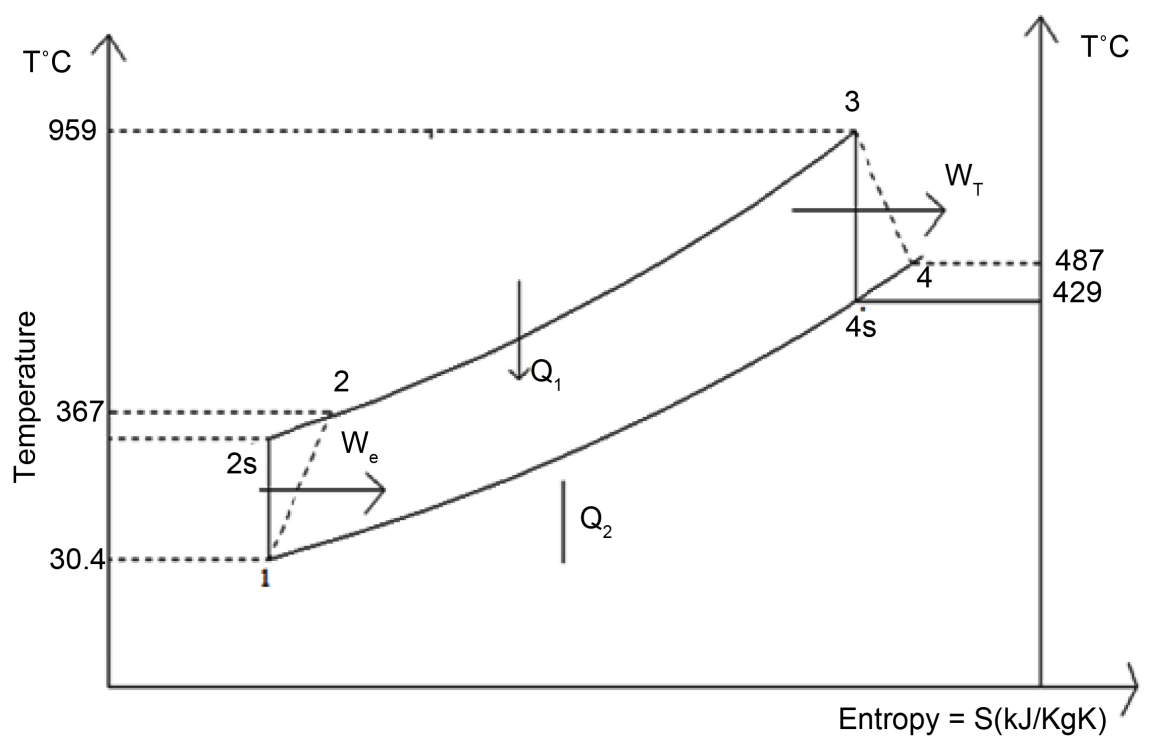

Figure 1. T-S diagram of the trans-amadi gas turbine power plant.

$$
\text { Turbine work rate, } \dot{W}_{t}=\dot{m} c_{p}\left(T_{3}-T_{4}\right)
$$

Turbine Inlet Temperature $T_{3}=\frac{m_{f} \times C V}{\left(m_{a}+m_{f}\right) \times C_{p a}}+T_{2}$

$$
\text { Specific Fuel Consumption sfc }=\frac{3600 \times m_{f}}{W_{\text {net }}}
$$

(Lebele-Alawa and Anthony, [22]; De and Nag, [23]).

$$
\begin{aligned}
& \text { Thermal efficiency }=\frac{\text { Net work Output }}{\text { Heat Supplied }} \\
& \qquad \eta_{\text {thGT }}=\frac{\left(T_{3}-T_{4}\right)-\left(T_{2}-T_{1}\right)}{T_{3}-T_{2}}=\frac{W_{\text {net }}}{\dot{Q}_{1}} \\
& \text { Isentropic Efficiency of the turbine } \eta_{i s}=\frac{\left(T_{3}-T_{4}\right)}{T_{3}-T_{4 s}}
\end{aligned}
$$

Nag, [3].

\section{Economic Model for the Plant Investment Viability}

The need for a terminal form of power or energy is on the increase and more potential investments can maximize this opportunity. It is therefore necessary to rank the possible power production investment based on financial return. The financial analysis requires evaluation models that compare the time-based income stream generated from the investment with the cost of investment. The techno-economic viability of power plant projects can be forecasted using various criteria that can be adopted to carry out such a comparison; such as the net present value (NPV), payback-period (PBP) and internal rate of return (IRR) [24]. 
The Net Present Value (NPV) is used to assess the future series of after-tax cash flow (ATCF) generated for the power generation and utilization. The NPV of the financial benefits is compared with the NPV of the investment to determine whether the investment has a positive return [25]. Mathematically, NPV is expressed as

$$
\mathrm{NPV}=-F_{o}+\sum_{t=1}^{N} \frac{F_{t}}{\left(1+d_{t}\right)^{t}}
$$

(Nkoi et al., [24]).

The NPV of the cash flows calculated is then compared with the NPV of the investment sequence, which is determined by:

$$
\mathrm{NPV}_{\mathrm{IC}}=\sum_{i=0}^{i m n} \frac{I C_{i}}{\left(1+r_{c}\right)^{i}}
$$

where $i, m$ and $n$ are investment period index, maintenance costs and number of financial year respectively.

If $\mathrm{NPV}_{\mathrm{ATCF}}$ is greater than $\mathrm{NPV}_{\mathrm{IC}}$, the investment provides a positive return. Profitability index is defined as the ratio of the financial return to the investment. Appendix A shows a flowchart for NPV calculation. A negative NPV denotes that an investment is not economically viable, whereas an NPV equal to or greater than zero denotes an economically viable power investment.

The payback-period (SPBP) is the length of time usually in years taken to recover the initial cost of investment of the implementing plant based on the annual savings realized. That is,

$$
\operatorname{PBP}(\text { years })=\frac{\text { Capital investment cost of the plant }}{\text { Annual saving from the Energy Generated by the plant }}
$$

\section{Results and Discussions}

\section{Results}

\section{Thermodynamic Performance of the Plant}

Data recorded from the HMI in the control room of the plant is presented in Table 1. MATLAB software was employed to evaluate the performance of Trans-Amadi $25 \mathrm{MW}$ gas turbine by calculating the percentage drops in power and thermal efficiency as the ambient temperature increases.

From the performance and economic analyses of Trans-Amadi gas turbine, Figures 2-4 were generated.

Figure 2 shows the effect of ambient temperature on the net power. It was observed that percentage power drop increases with increase in ambient temperature. It indicated that for every $1^{\circ} \mathrm{C}$ rise in the ambient temperature, the percentage power drop increases by $2.07 \%$ for the period under consideration. This further revealed that as the deviation between the design and operating ambient temperature increases, the plant performance decreases proportionally.

In Figure 3, as the ambient temperature (compressor inlet) increases, the 
Table 1. Trans-Amadi $25 \mathrm{MW}$ gas turbine performance.

\begin{tabular}{|c|c|c|c|c|c|c|c|c|c|}
\hline $\begin{array}{l}\text { Ambient } \\
\text { Temp. } \\
\left({ }^{\circ} \mathrm{C}\right)\end{array}$ & $\begin{array}{c}\text { Compressor } \\
\text { Exit Temp. } \\
\left({ }^{\circ} \mathrm{C}\right)\end{array}$ & $\begin{array}{c}\text { Air } \\
\text { Mass } \\
\text { Flow } \\
(\mathrm{kg} / \mathrm{s})\end{array}$ & $\begin{array}{c}\text { Exhaust } \\
\text { Temp. } \\
\left({ }^{\circ} \mathrm{C}\right)\end{array}$ & $\begin{array}{l}\text { Fuel } \\
\text { Flow } \\
(\mathrm{kg} / \mathrm{s})\end{array}$ & $\begin{array}{c}\text { Actual } \\
\text { Power } \\
\text { Output } \\
\text { (MW) }\end{array}$ & $\begin{array}{c}\text { Thermal } \\
\text { Efficiency } \\
(\%)\end{array}$ & $\begin{array}{c}\mathrm{Sfc} \\
(\mathrm{kg} / \mathrm{MW}-\mathrm{s})\end{array}$ & $\begin{array}{c}\text { Power } \\
\text { Drop } \\
(\%)\end{array}$ & $\begin{array}{l}\text { Thermal } \\
\text { Efficiency } \\
\text { Drop (\%) }\end{array}$ \\
\hline 24 & 319.22 & 126.27 & 547.23 & 2.64 & 20.44 & 21.55 & 0.099 & 18.44 & 18.98 \\
\hline 25 & 332.51 & 122.90 & 554.09 & 2.55 & 19.92 & 20.78 & 0.102 & 20.42 & 21.87 \\
\hline 26 & 345.84 & 120.10 & 561.12 & 2.47 & 19.22 & 21.01 & 0.105 & 23.21 & 21.02 \\
\hline 27 & 359.12 & 117.39 & 568.37 & 2.39 & 19.12 & 20.24 & 0.108 & 23.62 & 23.91 \\
\hline 28 & 372.41 & 114.77 & 575.18 & 2.32 & 17.92 & 19.51 & 0.112 & 28.43 & 26.65 \\
\hline 29 & 385.71 & 112.24 & 582.04 & 2.25 & 17.01 & 19.07 & 0.116 & 31.96 & 28.31 \\
\hline 30 & 399.00 & 109.79 & 589.13 & 2.18 & 16.91 & 18.93 & 0.119 & 32.36 & 28.83 \\
\hline 31 & 412.31 & 107.42 & 596.42 & 2.11 & 15.51 & 18.16 & 0.124 & 38.13 & 31.73 \\
\hline 32 & 425.62 & 105.13 & 603.33 & 2.05 & 15.51 & 18.01 & 0.129 & 38.20 & 32.29 \\
\hline
\end{tabular}

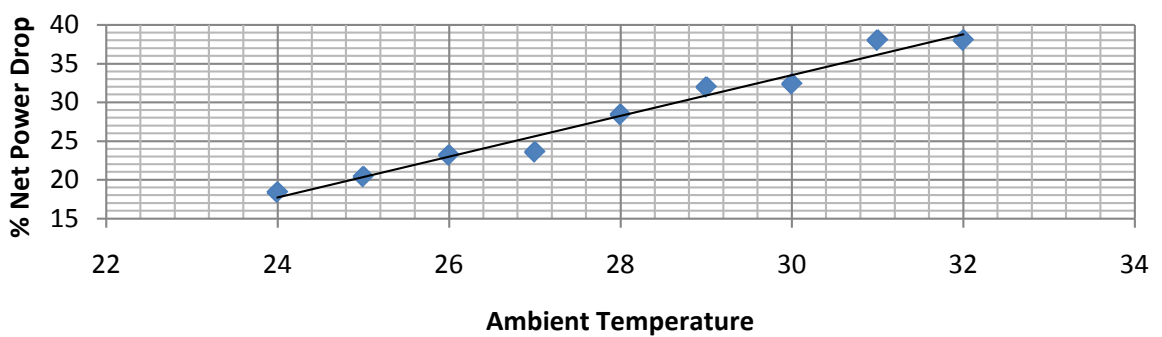

Figure 2. Variations in percentage net power drop with ambient temperature.

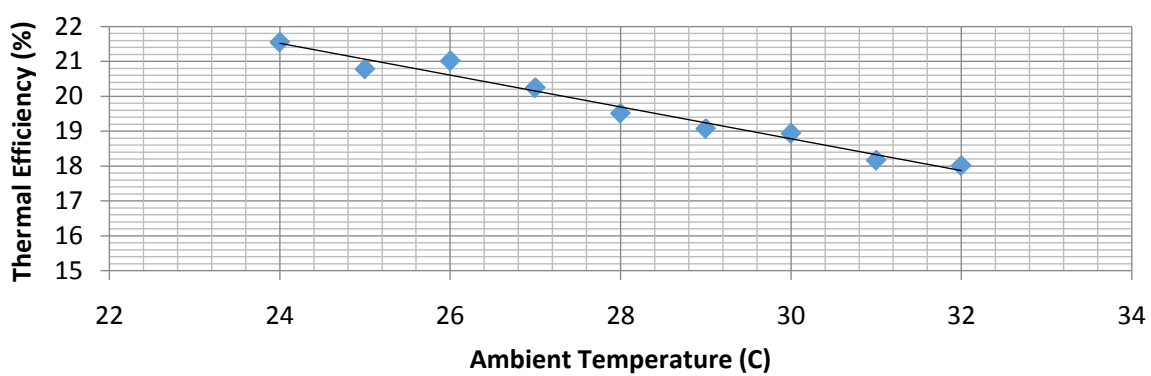

Figure 3. Variation of thermal efficiency with ambient temperature.

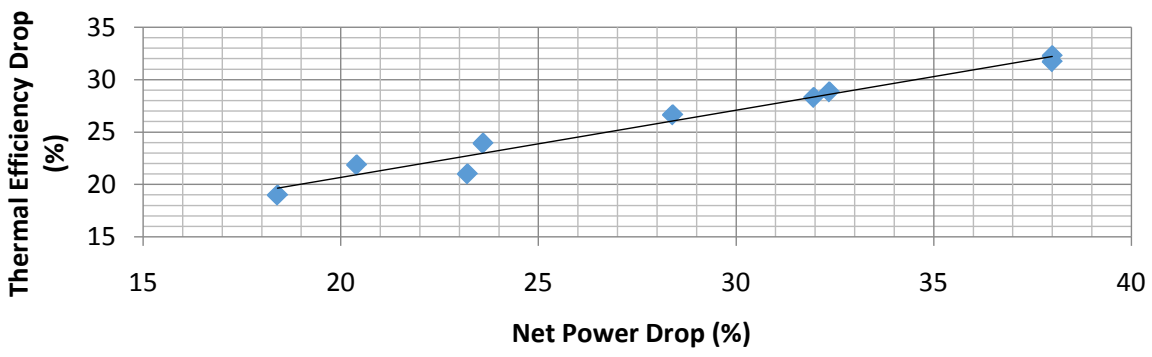

Figure 4. Variation of thermal efficiency with percentage power drop.

compressor work required for compressing the hot air increases resulting to decrease in thermal efficiency of the plant. For every $1^{\circ} \mathrm{C}$ rise in the ambient tem- 
perature, the thermal efficiency drops by $0.66 \%$ for the period of analysis.

Figure 4 shows that as the net power drop increases there is a progressive increase in the thermal efficiency drop for the given range of ambient temperatures. Since the efficiency is a function of the output, increase in output will bring about a corresponding increase in efficiency. This is because both parameters are relatively proportional. For every $1 \%$ drop in the power output, the percentage thermal efficiency drops by $0.79 \%$ for the given consideration.

Figure 5 shows that specific fuel consumption (SFC) of the engine increases with increase in ambient temperature even though there is a decrease in fuel flow as shown above. This is because as the temperature increases, just any little available fuel will cause ignition whereas, any available fuel will be swept up (consumed) by the increased temperature. For every $1^{\circ} \mathrm{C}$ rise in the ambient temperature, the specific fuel consumption increases by $0.93 \%$ for the given period.

\section{Energy-Cost Analysis of the Gas Turbine Plant Performance}

The analysis of the plant performance was evaluated on monthly basis. This was statistically evaluated and the average tabulated. Further analysis revealed the power available and power shortages due to the difference between the installed capacity and the generated power as shown in Table 2.

The log sheet data were evaluated and the mean net electrical power generated was 18.3 MW for a period of one year and the plant operating hours was 663 hours.

Power Available for the period (KWhe) $=$ Net Electrical Power Generated $\times$ Operating Hours.

Power Available for the period $($ KWhe $)=18.3 \times 663 \times 1000=12,132,900$ kWhe.

Power Shortages $(\mathrm{MW})=$ Installed capacity - Net power generated $=25 \mathrm{MW}-$ 18.3 MW = 6.7 MW.

Revenue Generated $=$ Power available $($ KWhe $) \times$ Electricity tariff $(\mathbb{N} / \mathrm{kWh}$ or $\$ / \mathrm{kWh}$ ).

Where the electricity tariff $=24.91 \mathrm{~N} / \mathrm{KWh}(\mathrm{NERC}, 2015)(0.076 \$ / \mathrm{KWh}$, approx $0.08 \$ / \mathrm{KWh}$ ).

Revenue Generated $=12,132,900 \mathrm{KWhe} \times 24.91 \mathrm{NWh}=\$ 302,230,539$ $(\$ 970,632)$.

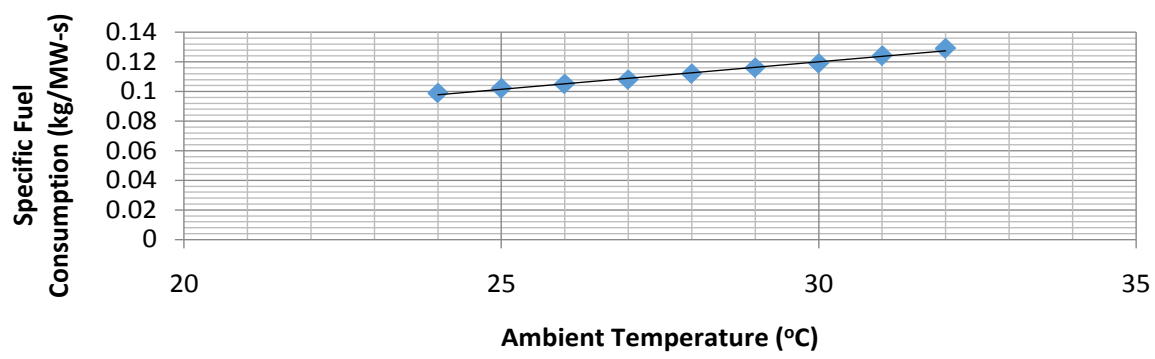

Figure 5. Variation of specific fuel consumption with ambient temperature for transamadi gas turbine. 
B. Nkoi et al.

Table 2. Summary of trans-amadi gas turbine annual operating performance.

\begin{tabular}{cccccccc}
\hline $\begin{array}{c}\text { Month of } \\
\text { Operation }\end{array}$ & $\begin{array}{c}\text { Net Electrical } \\
\text { Power Generated } \\
\text { (Avrg) }(\mathrm{MW})\end{array}$ & $\begin{array}{c}\text { Hour of Plant } \\
\text { Operation } \\
(\mathrm{hr})\end{array}$ & $\begin{array}{c}\text { Power } \\
\text { Available } \\
(\mathrm{kWhe})\end{array}$ & $\begin{array}{c}\text { Power } \\
\text { Shortages } \\
(\mathrm{MW})\end{array}$ & $\begin{array}{c}\text { Available Power } \\
\text { Revenue } \$ / \mathrm{kWhe}\end{array}$ & $\begin{array}{c}\text { Cost of } \\
\text { Shortages } \\
\$ / \mathrm{kWhe}\end{array}$ & $\begin{array}{c}\text { Cost of outages } \\
\$ / \mathrm{kWhe}\end{array}$ \\
\hline January & 18.3 & 663 & $12,132,900$ & 6.7 & 970,632 & 337599.6 & 79275.6 \\
February & 18.9 & 606 & $11,453,400$ & 6.1 & 916,272 & 280941.6 & 163749.6 \\
March & 19.3 & 500 & $9,650,000$ & 5.7 & 772,000 & 216,600 & 322,696 \\
April & 19.6 & 460 & $9,016,000$ & 5.4 & 721,280 & 188,784 & 387,296 \\
May & 18.2 & 566 & $10,301,200$ & 6.8 & 824,096 & 292508.8 & 213012.8 \\
June & 15.7 & 540 & $8,478,000$ & 9.3 & 678,240 & 381,672 & 214,776 \\
July & 15.9 & 580 & $9,222,000$ & 9.1 & 737,760 & 401,128 & 169,176 \\
August & 20.1 & 605 & $12,160,500$ & 4.9 & 972,840 & 225,302 & 175,674 \\
September & 11.4 & 580 & $6,612,000$ & 13.6 & 528,960 & 599,488 & 121,296 \\
October & 15.2 & 667 & $10,138,400$ & 9.8 & 811,072 & 496781.6 & 61225.6 \\
November & 14.6 & 460 & $6,716,000$ & 10.4 & 537,280 & 363,584 & 288,496 \\
December & 15.6 & 580 & $9,048,000$ & 9.4 & 723,840 & 414,352 & 165,984 \\
Total & & & $114,928,400$ & & $9,194,272$ & $4198,741.6$ & 2362657.6 \\
\hline
\end{tabular}

Cost of Shortages $=($ Installed capacity - Net power generated $) \times$ Operating hour $\times$ Electricity Tariff.

Cost of shortages $=(25 \mathrm{MW}-18.3 \mathrm{MW}) \times 663$ hours $\times 24.91 / \mathrm{KWh}=$ N110,652,711 (\$337599.6).

Cost of Outages $=($ Total hours in the Month - Plant operating hours $) \times$ Net electrical power generated $\times$ Electricity Tariff $=(720-663$ hours $) \times 18.3 \times 10^{3}$ $\mathrm{kW} \times 24.91 \mathrm{NWh}=\mathrm{k} 25,983,621(\$ 79275.6)$.

The economic analysis based on the performance revealed that the power shortages represent about $47.9 \%$ of the net power generated for the period of consideration. This represents revenue loss of about $\$ 4198741.60$ for the period. It further shows that the cost of outages represents $35.7 \%$ of the revenue generated per annum for the operating hours of the plant.

\section{Investment Analysis of the Gas Turbine Plant}

Reference to [24] [26] [27], the estimated gas turbine capital cost $(\$ / \mathrm{kW})$ is 1167.95, gas turbine operation and maintenance $(\mathrm{O} \& \mathrm{M})$ cost $(\$ / \mathrm{kW})$ is 0.00939 , gas turbine fuel cost $(\$ / \mathrm{kWh})$ is 0.0469 .

The Annual Operational and Maintenance cost for year $1=$ Total annual power generated $\times \mathrm{O} \& \mathrm{M}$ cost per $\mathrm{kWh}=114,928,400 \times 0.00939=\$ 1,079,178$.

The Annual GT Fuel cost for year $1=$ Total annual power generated $\times$ Fuel Price per $\mathrm{kWh}=114,928,400 \times 0.0469=\$ 5,390,142$.

The Annual Net Cash Flow = Annual Electricity Revenue - (Annual O \& M cost + Annual Fuel cost $)=\$ 9194272-(\$ 1,079,178+\$ 5,390,142)=\$ 2,724,952$.

Present Value(10\% discount rate) for year 1

$$
=\frac{\text { Annual net cash flow }\left(F_{t}\right)}{(1+\text { discount rate })^{t}}=\frac{2724952}{(1+0.1)^{1}}=\$ 2477229.09
$$


Initial Cash Flow $F_{0}=(1 \times 25$ MWGT $) \times$ Capital Cost per kW.

Initial Cash Flow $F_{0}=(1 \times 25,000 \mathrm{~kW}) \times 1167.95 \$ / \mathrm{kW}=\$ 29,198,750$.

Table 3 shows the result of the economic viability of the plant based on performance. The analysis takes into consideration the investment cost, operation and maintenance (O\&M) cost and fuel cost. This gives the financial details on the project investment, cost of running the plant and possible profitability on investment. Although, the depreciation cost was not considered in the maintenance cost evaluation.

$$
\begin{aligned}
& \text { The Net Present Value NPV } V_{\text {SGT }} \\
& =\text { Total life cycle present value }- \text { Initial cash flow } \\
& =\$ 35633649.97-\$ 29198750=\$ 6434899.97
\end{aligned}
$$

The NPV value shows that the plant investment is viable for the period of twenty years in operation. Although the estimate was done at the performance rating of approximately $70 \%$ based on the drop-in power output and efficiency. Also, the internal rate of return on investment was determined to be $12.40 \%$ by a

\begin{tabular}{|c|c|c|c|c|c|}
\hline End of year & $\begin{array}{c}\text { GT O \& M Cost } \\
\text { GTO \& M }(3 \% \\
\text { escalation rate })(\$)\end{array}$ & $\begin{array}{l}\text { GT Fuel Cost GT } \\
\text { (3\% escalation) (\$) }\end{array}$ & $\begin{array}{c}\text { GT Annual Electricity } \\
\text { Revenue } \mathrm{GT}_{\mathrm{RE}}(\$) \\
\text { (4\% escalation due to tariff inc) }\end{array}$ & $\begin{array}{l}\text { GT Annual net } \\
\text { cash flow } F_{t}(\$)\end{array}$ & $\begin{array}{l}\text { Present value (\$) } \\
\qquad F_{t} /(1+d)^{t}\end{array}$ \\
\hline 1 & $1,079,178$ & $5,390,142$ & $9,194,272$ & $2,724,952$ & $2,477,229.090$ \\
\hline 2 & $1,112,275.37$ & $5,561,376.85$ & $9,562,042.88$ & $2,888,390.66$ & $2,387,099.719$ \\
\hline 3 & $1,145,643.631$ & $5,728,218.156$ & $9,944,524.595$ & $3,070,662.809$ & $2,308,769.029$ \\
\hline 4 & $1,180,012.94$ & $5,900,064.7$ & $10,342,305.58$ & $3,262,227.939$ & $2,234,402.698$ \\
\hline 5 & $1,215,413.328$ & $6,077,066.641$ & $10,755,997.8$ & $3,463,517.833$ & $2,151,253.312$ \\
\hline 6 & $1,251,875.728$ & $6,259,378.64$ & $11,186,237.71$ & $3,674,983.346$ & $2,076,261.777$ \\
\hline 7 & $1,289,432$ & $6,447,160$ & $11,633,687.22$ & $3,897,095.223$ & $1,998,510.371$ \\
\hline 8 & $1,328,114.96$ & $6,640,574.8$ & $12,099,034.71$ & $4,130,344.952$ & $1,930,067.735$ \\
\hline 9 & $1,367,958.409$ & $6,839,792.044$ & $12,582,996.1$ & $4,375,245.648$ & $1,853,917.647$ \\
\hline 10 & $1,408,997.161$ & $7,044,985.805$ & $13,086,315.94$ & $4,632,332.978$ & $1,788,545.551$ \\
\hline 11 & $1,451,267.076$ & $7,256,335.379$ & $13,609,768.58$ & $4,902,166.127$ & $1,720,058.29$ \\
\hline 12 & $1,494,805.088$ & $7,474,025.44$ & $14,154,159.33$ & $5,185,328.797$ & $1,651,378.598$ \\
\hline 13 & $1,539,649.241$ & $7,698,246.204$ & $14,720,325.7$ & $5,482,430.254$ & $1,589,110.219$ \\
\hline 14 & $1,585,838.718$ & $7,929,193.59$ & $15,309,138.73$ & $5,794,106.419$ & $1,528,787.973$ \\
\hline 15 & $1,633,413.879$ & $8,167,069.397$ & $15,921,504.28$ & $6,121,020.998$ & $1,464,359.091$ \\
\hline 16 & $1,682,416.296$ & $8,412,081.479$ & $16,558,364.45$ & $6,463,866.671$ & $1,408,249.819$ \\
\hline 17 & $1,732,888.785$ & $8,664,443.924$ & $17,220,699.02$ & $6,823,366.316$ & $1,348,491.367$ \\
\hline 18 & $1,784,875.448$ & $8,924,377.241$ & $17,909,526.99$ & $7,200,274.295$ & $1,295,013.362$ \\
\hline 19 & $1,838,421.712$ & $9,192,108.559$ & $18,625,908.06$ & $7,595,377.794$ & $1,241,074.803$ \\
\hline 20 & $1,893,574.363$ & $9,467,871.815$ & $19,370,944.39$ & $8,009,498.209$ & $1,190,118.605$ \\
\hline Total & $29,016,753.13$ & $145,083,765.70$ & $273,787,754.10$ & $99,687,235.27$ & $35,633,649.97$ \\
\hline
\end{tabular}
numerical approximation technique.

Table 3. Result of the investment analysis of the gas turbine plant. 


\section{Conclusions}

The thermo-economic assessments of this plant type provide a significant detail on the plants performances. The various performance indicators reveal that the SGT shows a good performance in terms of thermal efficiency, fuel consumption, power output, return on investment at lower ambient temperature with positive NPV and payback period. The analysis further indicates that the higher IRR and cash flow exceed the cost of investment, the higher the net cash flow to the investor.

Strategically, the analysis shows that the plant performs better at lower ambient temperature with greater air mass inflow. This is reflected in the net power generated and the net cash flow. The payback period was used to analyze investment risk and identify the breakeven point on investment. The payback decreases as the NPV increases as analyzed. Although there may be associated uncertainty with respect to the assumptions, this result provides a great insight on technical and economic perspective for energy system operators and investor in decision making and planning. It also provides critical information for power plants types and operational costs.

\section{References}

[1] Rao, S. and Parulekar, B.B. (2007) Energy Technology; Non-Conventional, Renewable and Conventional, Romesh Chander Khanna. Khanna Publishers, Naisarak, Delhi.

[2] Goswami, D.Y. and Kreith, F. (2008) Energy Conversion. CRC Press, Taylor and Francis Group, Boca Ranton, London, New York.

[3] Nag, P.K. (2011) Power Plant Engineering. 3rd Edition, Tata McGraw-Hill Education Private Limited, New Delhi, India.

[4] Mohamed, K.M. (2005) Parametric Analysis of Advanced Combined Power Generation Systems. M.Sc. in Engineering Thesis, University of New Brunswick, Fredericton and Saint John.

[5] Domkundwar, V.M. (2011) A Course on International Combustion Engines. 3rd Revised Edition, Dhanpatrai and Co. (P) Ltd. Delhi.

[6] Ideriah, F.J.K. (1986) An Introduction to Fluid Machinery. Lecture Material, Rivers State University of Science and Technology, Port-Harcourt.

[7] Martha De Souza, G.M. (2012) Thermal Power Plant Performance Analysis. Springer-Verlag, London. https://doi.org/10.1007/978-1-4471-2309-5

[8] Achuthan, M. (2009) Engineering Thermodynamics. 2nd Edition, PHI Learning Private Limited, New Delhi.

[9] Briesch, M.S., Bannister, R.L., Diakunchak, I.S. and Huber, D. (1995) A Combined Cycle Design to Achieve Greater than 60 Percent Efficiency. Journal of Engineering for Gas Turbine and Power, 117, 734-741. https://doi.org/10.1115/1.2815459

[10] Adumene, S. (2015) Load-Based Exergetic Assessment of an Offshore Thermal Power Plant in an Equatorial Environment. Studies in Engineering and Technology, 3, 19-27. https://doi.org/10.11114/set.v3i1.1177

[11] Eti, M.C., Ogaji, S.O.T. and Probert, S.D. (2004) Reliability of the Afam Electric Power Generating Station, Nigeria. Journal of Applied Energy, 77, 309-315. 
https://doi.org/10.1016/S0306-2619(03)00094-1

[12] Thamir, K.I., Rahman, M. and Ahmed, N. (2010) Improvement of Gas Turbine Performance Based on Inlet Air Cooling Systems: A Technical Review. International Journal of Physical Sciences, 6, 620-627.

[13] Bhargava, R.K., Bianchi, M., Campanari, S., De Pascal, A., Negri Di Montenegro, G. and Perotto, A. (2010) A Parametric Thermodynamic Evaluation of High Performance Gas Turbine Based Power Cycles. Journal of Engineering for Gas Turbines and Power, 132, 23-28. https://doi.org/10.1115/1.3155782

[14] Nkoi, B., Pilidis, P. and Nikolaidis, T. (2013) Performance Assessment of Simple and Modified Cycle Turboshaft Gas Turbine. Propulsion and Power Research, 3, 96-106. https://doi.org/10.1016/j.jppr.2013.04.009

[15] Espanni, R., Ebrahimi, S.H. and Ziaeimoghadam, H.R. (2013) Efficiency Improvement Methods of Gas Turbine. Energy and Environmental Engineering, 1, 36-54.

[16] Adumene, S., Le-ol, A.K. and Amadi, R.K.C. (2015) Modelling Compressor's Initial Operating Conditions Effect on Turbine Performance in the Tropical Rainforest. American Journal of Engineering Research, 4, 80-88. http://www.ajer.org

[17] Wang, F.J. and Chiou, J.S. (2004) Integration of Steam Injection and Inlet Air Cooling for a Gas Turbine Generation System. Energy Conversion and Management, 45, 15-26. https://doi.org/10.1016/S0196-8904(03)00125-0

[18] Bouam, A., Aïssani, S. and Kadi, R. (2008) Gas Turbine Performances Improvement Using Steam Injection in the Combustion Chamber under Sahara Conditions. Oil and Gas Science and Technology, 63, 251-261. https://doi.org/10.2516/ogst:2007076

[19] Horlock, J.H., Young, J.B. and Manfrida, G. (2000) Exergy Analysis of Modem Fossil-Fuel Power Plants. ASME Journal of Engineering for Gas Turbines and Power, 122, 1-7. https://doi.org/10.1115/1.483170

[20] Srinivas, T., Gupta, A.V.S.S.K.S. and Reddy, B.V. (2007) Generalized Thermodynamic Analysis of Steam Power Cycles with "N" Number of Feedwater Heaters. International Journal of Thermodynamics, 10, 177-185.

[21] Wadhah, H.A.R.A. (2011) Parametric Performance of Gas Turbine Power Plant with Effect Intercooler. Modern Applied Science, 5.

[22] Lebele-Alawa, B.T. and Le-ol, A.K. (2015) Improved Design of a 25 MW Gas Turbine Plant Using Combined Cycle Application. Journal of Power and Energy Engineering, 3, 1-14. https://doi.org/10.4236/jpee.2015.38001

[23] De, S. and Nag, P.K. (2000) Effect of Supplementary Firing on the Performance of an Integrated Gasification Combined Cycle Power Plant. Proceedings of the Institution of Mechanical Engineers, Part A: Journal of Power and Energy, 214.

[24] Nkoi, B., Pilidis, P. and Nikolaidis, T. (2015) Techno-Economic Assessment of Large Scale Aero-Derivative Industrial Gas Turbines Combined-Heat-and-Power. International Journal of Engineering and Technology, 5, 225-240.

[25] Brealey, R.A. and Meyers, S.C. (2003) Principles of Corporate Finance. The Ed. McGraw-Hill Irwin, New York.

[26] National Renewable Energy Laboratory (NREL) (2012) Cost and Performance Data for Power Generation Technologies. Black and Veatch Corporation, 9-35.

[27] Environmental Protection Agency Climate Protection Partnership Division (EPACPPD) (2008) Technology Characterization: Gas Turbines. Washington DC. http://www.epa.gov/chp/documents/catalog_chptech_gas_turbines.pdf 
Appendix A. Flow Chart for Gas Turbine Performance Calculations

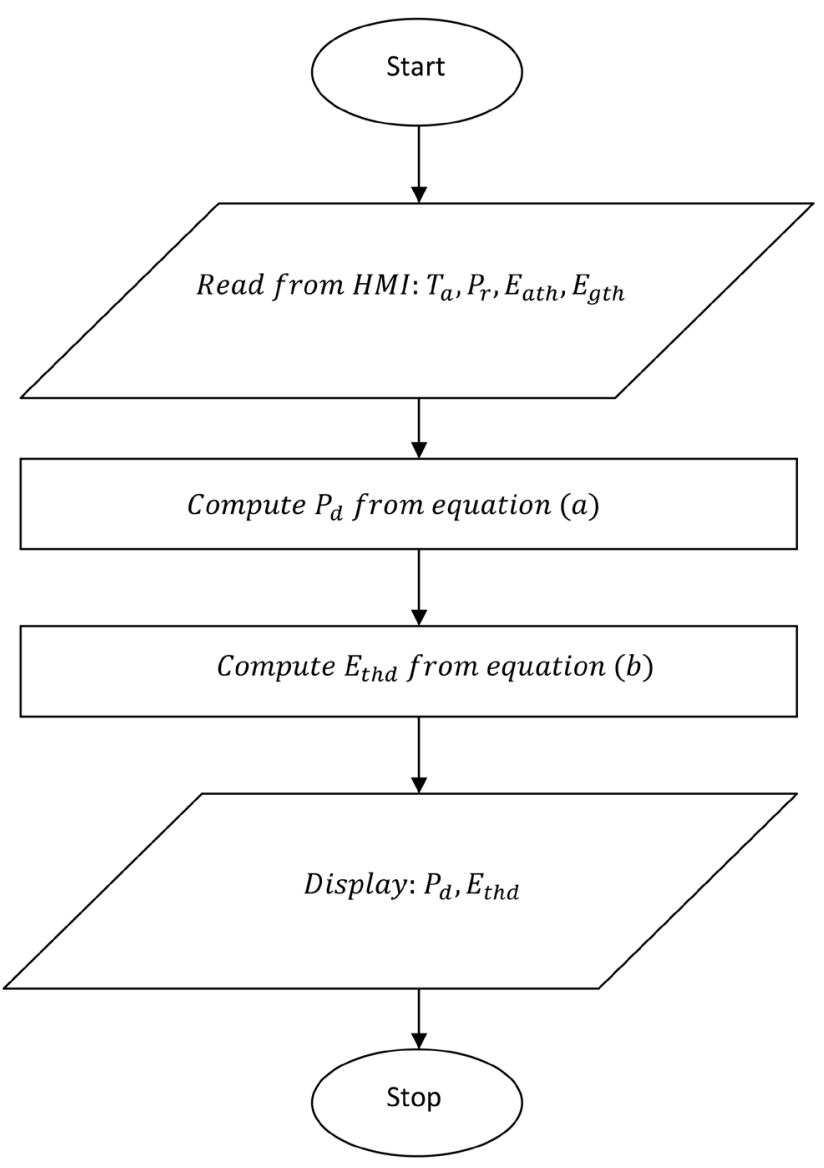

\section{Nomenclature}

$C_{p} \quad$ Specific heat constant pressure, $\mathrm{kJ} / \mathrm{kg} \cdot \mathrm{K}$

$\dot{m}$ Mass flaw rate, $\mathrm{kg} / \mathrm{s}$

$T_{3}$ Turbine inlet temperature, ${ }^{\circ} \mathrm{C}$

$\mathrm{T}_{2}$ Compressor exit temperature, ${ }^{\circ} \mathrm{C}$

$T_{1}$ Compressor inlet temperature, ${ }^{\circ} \mathrm{C}$

$\mathrm{T}_{4}$ Turbine exit temperature, ${ }^{\circ} \mathrm{C}$

$m_{a}$ Air mass flow rate, $\mathrm{kg} / \mathrm{s}$

$m_{f}$ Fuel mass flow rate, $\mathrm{kg} / \mathrm{s}$

$C_{p a}$ Specific heat capacity of air, $\mathrm{KJ} / \mathrm{kg}-\mathrm{K}$

$\mathrm{CV}$ Calorific value

$W_{\text {net }}$ Net work, MW

$\eta_{\text {thGT }}$ Thermal efficiency

$N P V$ Net present value

$F_{0}$ Initial cash flow

$F_{t}$ Annual net cash flow

$d_{t}$ Discount rate 